\title{
African Business Schools: Information and Communication Technology Survey
}

\author{
PKJ Tobin, Gordon Institute of Business Science, University of Pretoria, South Africa
}

Purpose: The aim of this paper is to report on research into the status of information and communication technology in use at members of the Association of African Business Schools (AABS).

Design/Methodology/Approach: The research reported on in this paper was carried out using a questionnaire sent by email to the target population (all the members of the AABS). The questionnaire covered a wide range of issues, including information technology strategy and governance, as well as the operational aspects of the use of Information and Communication Technology (ICT) in the institutions surveyed. Questions were based on topics identified from the literature and a recent industry survey conducted in one of the member countries, and the assessment criteria were based on a maturity rating scale.

Findings: This research helps to further an understanding of the use of ICT in the organisations that responded to the survey. Overall, there was a high level of understanding or applicability (over 95\%) among the topics surveyed across all schools, but there was a significant proportion where no action on that topic had yet been taken (over $30 \%$ of all maturity ratings across all respondents). Average maturity rating across all topics for all respondents was 2.3 (action taken but an informal approach to the topic is currently used) on a scale from 0 to 5.

Implications: This research has important implications for the organisations responding to the survey and their awareness of the issues they face as institutions that seek to leverage their investments in ICT to raise their own competitive position and thus that of African organisations which have students educated at these business schools. There are also implications for the future success of the newly-formed AABS and its other initiatives in terms of meeting the objectives of the Association.

Originality/Value: This research is original in terms of which there is a broad understanding of the extent to which ICT is available and in use amongst the members of the AABS. Prior to the foundation of the Association, no suitable forum existed for the conduct of this research. The originality therefore, is in the opportunity presented to form a broader understanding of the status of the use of ICT to support the activities of business schools across Africa. The value of this research may be applied to both those respondents to the survey, other members of the AABS and other business schools operating in Africa that wish to understand the issues in the field of ICT that they should be addressing.

Key words and phrases: Africa; African Association of Business Schools; business schools; communications technology; information technology; management education.

\section{INTRODUCTION}

It is well recognised that there is a significant need for primary and secondary education to meet the needs of the population of more than 800 million people who live in the more than 50 countries found throughout the continent of Africa. However, the same cannot be said for management education on the continent. "The report of the Commission for Africa, which British Prime Minister Tony Blair submitted to the Group of Eight [G8] last July, rightly flags management weakness in nearly every sector: water, health, transportation, and education. Yet nowhere does the report mention the need to strengthen local management schools," (Pfeffermann, 2005:1). Management education can be provided at a number of levels, including that offered by university-linked business schools (Bschools) that address the learning needs and aspirations of a wide variety of potential students to help them in their work of building a better Africa, often involving significant challenges: "In today's world of global business, leaders need to be equipped with the tools to make tough decisions on a regular basis" (Binedell, 2006).

Many of the B-schools across the continent have been established for some time (in the case of the Graduate School of Management of the University of Pretoria, South Africa, since soon after the Second World War). However, there has until recently been relatively little formal cooperation between those institutions on a continent-wide level, despite the existence of some regional-level 
associations (Reed, 2006). This situation changed in October 2005 with the formation of the Association of African Business Schools (AABS), supported by the Global Business Schools Network and the World Bank's International Finance Corporation (Reed, 2006). The initial membership of the Association numbers fourteen B-schools (roughly $28 \%$ of all the schools in Africa) drawn from six countries out of the over fifty countries represented on the African continent (AABS, 2005 and Binedell, 2006). "While India has roughly 1000 business schools and the USA about 1200, Africa has no more than 50 [B-schools]" (Reed, 2006).

Table 1 shows the profile of the six countries from which the fourteen members are drawn. Also indicated in Table 1 for comparative purposes is the single country (Indonesia) which most closely matches the population size and total Gross Domestic Product (GDP) of the six countries combined.

Table 1: Profile of member countries of AABS

\begin{tabular}{|l|l|l|l|l|l|l|}
\hline $\begin{array}{l}\text { Countries } \\
\text { with AABS } \\
\text { members }\end{array}$ & $\begin{array}{l}\text { US\$ } \\
\text { GDP } \\
\text { Icapita }\end{array}$ & $\begin{array}{l}\text { World } \\
\text { ranking } \\
\text { GDP } \\
\text { Icapita }\end{array}$ & $\begin{array}{l}\text { US\$ } \\
\text { GDP } \\
\text { total } \\
\text { (000 } \mathbf{~ m n )}\end{array}$ & $\begin{array}{l}\text { World } \\
\text { ranking } \\
\text { GDP } \\
\text { total }\end{array}$ & $\begin{array}{l}\text { Population } \\
\text { (Millions) }\end{array}$ & $\begin{array}{l}\text { World } \\
\text { ranking } \\
\text { Population }\end{array}$ \\
\hline South Africa & 12000 & 78 & 533 & 23 & 44 & 29 \\
\hline Ghana & 2500 & 170 & 54 & 77 & 22 & 51 \\
\hline Senegal & 1800 & 188 & 21 & 115 & 12 & 72 \\
\hline Nigeria & 1400 & 201 & 174 & 49 & 132 & 11 \\
\hline Kenya & 1100 & 212 & 37 & 94 & 35 & 36 \\
\hline Tanzania & 700 & 227 & 27 & 103 & 37 & 35 \\
\hline Total & & & $\mathbf{8 4 6}$ & $\mathbf{1 8}$ & $\mathbf{2 8 2}$ & $\mathbf{6}$ \\
\hline Indonesia & $\mathbf{3 6 0 0}$ & $\mathbf{1 5 4}$ & $\mathbf{8 6 6}$ & $\mathbf{1 7}$ & $\mathbf{2 4 5}$ & $\mathbf{6}$ \\
\hline
\end{tabular}

\section{Source CIA (2006)}

The Association sees a clear role for itself: "By training current and future leaders in their home markets, business schools in Africa play a critical role in laying the groundwork for private sector development" (AABS, 2005). The governing board of the Association comprises academics drawn from South Africa, Ghana, Senegal, Kenya and Tanzania. The AABS aims to provide its members with a forum to discuss and develop the member institutions in a number of areas, including:

- Business and management education methods

- Capacity building, collaboration and quality improvement

- Information and knowledge dissemination

- Curriculum and faculty development

- Diverse activities of interest to its members (AABS, 2005)

Against this background of the formation of the AABS, this paper presents the results of a recent research project carried out to improve an understanding of the use of information and communication technology (ICT) as part of the strategy and operations of the members of the Association. This paper presents: the purpose of the research; the nature of the problem investigated; the research methodology used; the findings and analysis from the research; and concludes with observations about the implications and value of the research.

\section{PURPOSE OF THE RESEARCH}

The purpose of this research is to establish an initial (baseline) assessment of the status of the ICT in the members of the AABS. The ability to support the activities of the B-schools through the use of ICT has been recognised to be one of the factors contributing to their success (AABS, 2005). The primary motivation for the research was to contribute to the opportunity all the members of the Association have to achieve their stated objectives in terms of cooperation and learning in an effort to improve performance across the members of the Association, with a specific focus on ICT strategy and operations. 


\section{PROBLEM INVESTIGATED}

A number of authors (Applegate, McFarlan \& McKenney, 1999; Gordon \& Gordon, 1999 and Oz, 2006) have recognised that organisations need to enable their strategy and operations through the availability of ICT, and African B-schools should be no exception. Whilst the use of ICT may differ from organisation to organisation, between industries, and between countries (Applegate et al., 1999), there is nonetheless the opportunity for members of a community, such as those who are participating in the $A A B S$, to learn from each other and to improve their performance (Binedell, 2006 and Reed, 2006). Indeed, the opportunity to share best practice may provide a significant contributor to improving overall economic performance and competitive advantage (Elliott \& O'Dell, 1999).

The problem investigated, therefore, is the extent to which members of the AABS are currently able to perform in terms of their maturity of availability and use of aspects of ICT, both from a strategic and operational perspective. Part of the reason for the formation of the AABS was to facilitate learning within members of the organisation and to act as a lobbying group to improve funding for the members of the Association. Therefore, in pursuit of the objectives of the Association, this research was undertaken.

\section{RESEARCH METHODOLOGY}

The research methodology combined non-empirical and empirical research methods (Easterby-Smith, Thorpe \& Lowe, 1991; Hussey \& Hussey, 1997; Leedy \& Ormrod, 2001; Miles \& Huberman, 1994 and Welman \& Kruger, 1999). The non-empirical research focused on three key issues. First, was identifying the overall approach to the research method that would best meet the objectives of the research project. It was clear that empirical research techniques would be required, and a number of sources were consulted for advice on the appropriate use of such techniques. As the objectives of this research project were exploratory in nature, it was judged inappropriate to perform an in-depth gathering of data via case studies of the member institutions. However, it was recognised that this approach may be valid at a later stage as a separate research project.

Of the alternative methods identified for the conduct of research based on the gathering of empirical data, the survey method was selected as being the most practical and cost-effective (Hussey \& Hussey, 1997; Leedy \& Ormrod, 2001 and Miles \& Huberman, 1994). In addition, the quantitative rather than qualitative approach was used as this was judged to be more useful for what was essentially an exploratory type of research (Hussey \& Hussey, 1997). It was also recognised that the total number of members of the Association who would be invited to complete the survey represented a small size of the total population in terms of the application of statistical or quantitative analysis techniques during the research analysis phase (Leedy \& Ormrod, 2001 and Miles \& Huberman, 1994). However, it was felt that it was preferable to complete the survey and apply such techniques even though the target population was relatively small as there was a great deal to learn about the activities of its members so early in the life of the Association.

Given the geographical spread of the members of the Association, it would not have been costeffective to administer the structured questionnaire via a face-to-face interview. Given the dubious quality and relatively high cost of voice-based telecommunications support within some of countries of the target participants for the survey, the use of the telephone was eliminated as a means of administering the questionnaire. In addition, broad support for real-time (online) Internet connectivity could not be guaranteed, and therefore a web-based method of administering the questionnaire was also deemed not to be feasible. Furthermore, the reportedly poor state of postal communications within and between member countries of the Association and the potential delays and risks to the completion of the survey led to this distribution method being discounted. By contrast, all of the members of the Association confirmed at the initial meeting held in Lagos, Nigeria, in October 2005, that they were able to send and receive e-mails on a reliable basis. Therefore, this method of distributing the survey was selected.

The scope of the parameters to be used in measuring the use of ICT within the target research population was based on two primary sources. Although several authors were consulted to help in the identification of the set of questions to be included in the survey, the most appropriate was judged to be available from Applegate, McFarlan, and McKenney (1999), in terms of the strategic issues 
involved. However, given the fast-moving nature of the ICT industry, a more up-to-date source was required to identify the current technology issues involved. The researcher was himself responsible for the ICT function within one of the members of the Association, and could therefore draw on his own practical experience of the scope of the products and services in use in at least one member of the Association. Although this carried with it some degree of subjectivity in terms of the structure of the assessment instrument, this potential bias in the survey was counterbalanced by the use of a list of the technology issues of broader interest to users of ICT in one of the AABS member countries. This material was sourced from one of the leading role players in the ICT sector of the media industry in South Africa, ITWeb. In February, 2006, ITWeb launched their own online survey to the 35,000 recipients of their daily newsletter (ITWeb, 2006) in which survey the researcher participated. The researcher used his judgment to combine the most appropriate elements from Applegate et al. (1999), his own experience and the ITWeb survey in compiling the final list of the 40 questions included in the survey.

Rather than using a simple bi-polar, preference ranking or five-point Likert scale (Easterby-Smith et al., 1991; Leedy \& Ormrod, 2001; Miles \& Huberman, 1994 and Welman \& Kruger, 1999), it was decided to use a modified version of the maturity rating approach as advocated by Crosby (1979) and extensively used to support the Capability Maturity Model ${ }^{\circledR}$ (Best Practices LLC, 2003; Better product design, Undated; Garcia, Undated and SEI, 2002). This consisted of a scale from zero through five, where at the lowest level of maturity the activity is not being performed (for the purposes of this survey this was modified to include where the question was not understood or not applicable), to the highest level of maturity (where respondents were invited to assess themselves as being world-class) (see Table 2). In addition, respondents were given the opportunity to add comments against each of the questions to further explain their self-assessment of maturity. Finally, respondents were also invited to identify their top three priorities in terms of problems with their ICT strategy and operations, and, where feasible, to suggest the possible source of the solution.

Table 2: Maturity rating scale as used in this research

\begin{tabular}{|l|l|}
\hline Maturity rating criteria & Rating \\
\hline Do not understand / does not apply & 0 \\
\hline Understand but have taken no action & 1 \\
\hline Initial action, largely informal & 2 \\
\hline Formal approach, need to make progress & 3 \\
\hline Well established, others could learn from us & 4 \\
\hline Very well established, consider ourselves world-class & 5 \\
\hline
\end{tabular}

A non-probability sampling method (Easterby-Smith et al., 1991; Leedy \& Ormrod, 2001; Miles \& Huberman, 1994 and Welman \& Kruger, 1999) was used to identify the respondents to the survey. As the membership of the Association was only recruited in October 2005, and at the time of the survey numbered only 14 different B-schools spread across six African countries, it was deemed appropriate to include all the members of the association in the survey. The head of each B-school, who had been identified at the founding of the Association, was used as the contact point for the distribution of the survey. The survey was sent out from the office of the Association's secretariat in Johannesburg via e-mail, with a target completion date stated in the survey. A later reminder was sent to the survey recipients to encourage them to complete the survey and offering them assistance in doing so should that be necessary.

\section{FINDINGS}

Although the Association was relatively new (being formally established only six months prior to the survey being conducted), and therefore a high level of enthusiasm for the activities of the Association might reasonably have been expected, only 7 out of 14 members of the Association completed the survey by the requested return date. This may be because the request to complete the survey was not relayed to the individual responsible for ICT within those non-respondent institutions. The list of the number of participating member B-schools by country is shown in Table 3. Further discussion of 
the survey findings will not identify specific schools by name to ensure the confidentiality of the data supplied.

Table 3: Survey responses by AABS member countries

\begin{tabular}{|l|l|l|l|}
\hline $\begin{array}{l}\text { Countries with } \\
\text { AABS members }\end{array}$ & $\begin{array}{l}\text { Number of } \\
\text { members of } \\
\text { AABS }\end{array}$ & $\begin{array}{l}\text { Did reply } \\
\text { to the } \\
\text { survey }\end{array}$ & $\begin{array}{l}\text { Did not } \\
\text { reply to } \\
\text { the survey }\end{array}$ \\
\hline South Africa & 5 & 3 & 2 \\
\hline Kenya & 3 & 1 & 2 \\
\hline Nigeria & 2 & 1 & 1 \\
\hline Senegal & 2 & 1 & 1 \\
\hline Ghana & 1 & 1 & 0 \\
\hline Tanzania & 1 & 0 & 1 \\
\hline Total & $\mathbf{1 4}$ & $\mathbf{7}$ & $\mathbf{7}$ \\
\hline
\end{tabular}

Each of the 40 questions in the survey had a maximum score of five points on the self-assessment maturity rating scale. The total maturity score, average maturity rating for the 40 questions in total, and the overall standard deviation (SD) for those 40 questions are reported in Table 4 . The final two columns of the table also indicate the number of problems and comments reported per school.

Table 4: Survey data summary by respondent schools overall maturity

\begin{tabular}{|l|l|l|l|l|l|}
\hline $\begin{array}{l}\text { Respondent B- } \\
\text { school }\end{array}$ & $\begin{array}{l}\text { Total } \\
\text { maturity } \\
\text { score }\end{array}$ & $\begin{array}{l}\text { Average } \\
\text { maturity I } \\
\text { question }\end{array}$ & $\begin{array}{l}\text { Standard } \\
\text { deviation }\end{array}$ & $\begin{array}{l}\text { Problems } \\
\text { reported }\end{array}$ & $\begin{array}{l}\text { Comments } \\
\text { reported }\end{array}$ \\
\hline B-School G & 135 & 3.38 & 0.93 & 3 & 11 \\
\hline B-School F & 118 & 2.95 & 1.24 & 1 & 33 \\
\hline B-School E & 94 & 2.35 & 1.10 & 3 & 0 \\
\hline B-School D & 86 & 2.15 & 1.08 & 0 & 0 \\
\hline B-School C & 80 & 2.00 & 1.15 & 3 & 1 \\
\hline B-School B & 79 & 1.98 & 0.97 & 3 & 0 \\
\hline B-School A & 46 & 1.15 & 0.53 & 3 & 0 \\
\hline Total & $\mathbf{6 3 8}$ & & & $\mathbf{1 6}$ & $\mathbf{4 5}$ \\
\hline Average & $\mathbf{4 5 . 6 \%}$ & & & $\mathbf{2 . 2 9}$ & $\mathbf{6 . 4 3}$ \\
\hline
\end{tabular}

Table 4 also indicates the total and average percentage maturity score for all seven schools responding to the survey (reaching a cumulative maturity of 638 points out of a total of 1400). Only one school did not report any specific problems, and in terms of comments made, the two B-schools which scored highest in terms of total maturity also had the largest number of comments made. Table 5 shows the topic of each of the 40 questions in the survey, and these questions are sorted in terms of the highest to lowest average (mean) maturity rating across all seven schools for that particular question. The final column in the table indicates the SD calculated for the range of maturity ratings for that question across all seven schools.

Table 5: Survey responses by mean maturity distribution

\begin{tabular}{|l|l|l|l|}
\hline Qn \# & Question topic & $\begin{array}{l}\text { Average (mean) } \\
\text { maturity rating }\end{array}$ & $\begin{array}{l}\text { Standard } \\
\text { deviation }\end{array}$ \\
\hline $\mathbf{1 1}$ & Communications platforms definition & 3.3 & 1.3 \\
\hline $\mathbf{2 4}$ & Email usage main means of communication & 3.3 & 1.4 \\
\hline $\mathbf{3 5}$ & Internet web site for institution & 3.1 & 0.7 \\
\hline
\end{tabular}




\begin{tabular}{|l|l|l|l|}
\hline $\mathbf{3 0}$ & CD-ROM technology in use & 3.1 & 1.1 \\
\hline $\mathbf{3 1}$ & DVD playing facilities & 3.0 & 1.2 \\
\hline $\mathbf{1 0}$ & Computing platforms definition & 3.0 & 1.3 \\
\hline $\mathbf{9}$ & External technology partners & 2.9 & 1.1 \\
\hline $\mathbf{3}$ & IT function leadership & 2.7 & 1.1 \\
\hline $\mathbf{6}$ & Information policies defined & 2.7 & 1.1 \\
\hline $\mathbf{2 7}$ & Wi-Fi (wireless hotspots) for student use & 2.7 & 1.4 \\
\hline $\mathbf{4}$ & IT governance practice & 2.6 & 0.8 \\
\hline $\mathbf{2 8}$ & Personal memory stick in use & 2.6 & 0.8 \\
\hline $\mathbf{2 2}$ & Intranet deployment completed & 2.6 & 1.3 \\
\hline $\mathbf{1 2}$ & Information systems applications deployed & 2.6 & 1.5 \\
\hline $\mathbf{2 6}$ & Wi-Fi (wireless hotspots) for staff use & 2.4 & 1.5 \\
\hline $\mathbf{3 9}$ & Academic delivery/support via a web site & 2.4 & 1.6 \\
\hline $\mathbf{2 3}$ & Online staff diary deployed & 2.4 & 1.8 \\
\hline $\mathbf{7}$ & IT service management /delivery deployed & 2.3 & 1.1 \\
\hline $\mathbf{2 5}$ & SMS (text) messages deployed & 2.3 & 1.1 \\
\hline $\mathbf{1 3}$ & Collaboration systems deployed & 2.3 & 1.4 \\
\hline $\mathbf{3 7}$ & Online course applications deployed & 2.3 & 1.4 \\
\hline $\mathbf{8}$ & Level of IT expertise for staff & 2.3 & 1.5 \\
\hline $\mathbf{1 5}$ & Digital photographs used & 2.1 & 0.7 \\
\hline $\mathbf{1 7}$ & Audio conference facilities deployed & 2.1 & 1.1 \\
\hline $\mathbf{4 0}$ & Challenges to IT strategy execution identified & 2.1 & 1.1 \\
\hline $\mathbf{1}$ & Enterprise and process architecture deployed & 2.1 & 1.3 \\
\hline $\mathbf{2 0}$ & Call centre management deployed & 2.1 & 1.6 \\
\hline $\mathbf{3 2}$ & DVD recording facilities deployed & 2.0 & 0.8 \\
\hline $\mathbf{2}$ & IT strategy deployed & 1.0 \\
\hline $\mathbf{5}$ & IT resource allocation / prioritisation of projects & 2.0 & 1.5 \\
\hline $\mathbf{2 9}$ & Instant messaging deployed & 1.9 & 0.9 \\
\hline $\mathbf{3 8}$ & Academic material on CD/DVD deployed & 1.9 & 0.9 \\
\hline $\mathbf{1 6}$ & Video conference facilities available & 1.9 & 1.1 \\
\hline $\mathbf{1 9}$ & Voice Over Internet Protocol (VOIP) deployed & 1.9 & 1.1 \\
\hline $\mathbf{3 3}$ & Video editing facilities available & 1.7 & 0.8 \\
\hline $\mathbf{3 4}$ & Home broadband connection for staff available & 1.7 & 1.0 \\
\hline $\mathbf{2 1}$ & Open Source Software (OSS) deployed & 1.3 & 0.8 \\
\hline $\mathbf{1 4}$ & Business intelligence deployed & 1.1 & 0.4 \\
\hline $\mathbf{1 8}$ & Web cam available & 1.1 & 0.7 \\
\hline $\mathbf{3 6}$ & Student online payments received & 1.1 & \\
\hline & Overall average maturity rating for all topics & $\mathbf{2 . 3}$ & \\
\hline & & & \\
\hline
\end{tabular}

Table 5 also includes the overall average for all of the maturity ratings across all 40 questions for all seven schools (2.3). This indicates that initial action has taken place but remains at an informal level overall for the topics surveyed. Table 6 shows the distribution of maturity frequency across all seven schools responding to the survey. This table indicates that a high proportion of the issues identified in the survey (96.8\%) were understood or were applicable, whilst only a small proportion of the individual maturity ratings were in the highest category $(1.8 \%)$. 
Table 6: Survey data summary by maturity distribution

\begin{tabular}{|l|l|l|}
\hline $\begin{array}{l}\text { Maturity } \\
\text { rating }\end{array}$ & Frequency & \% of total \\
\hline $\mathbf{0}$ & 9 & $3.2 \%$ \\
\hline $\mathbf{1}$ & 85 & $30.4 \%$ \\
\hline $\mathbf{2}$ & 65 & $23.2 \%$ \\
\hline $\mathbf{3}$ & 66 & $23.6 \%$ \\
\hline $\mathbf{4}$ & 50 & $17.9 \%$ \\
\hline $\mathbf{5}$ & 5 & $1.8 \%$ \\
\hline Total & $\mathbf{2 8 0}$ & $\mathbf{1 0 0 . 0 \%}$ \\
\hline
\end{tabular}

Table 7 indicates the problem topics which have been identified by the respondents, including the frequency with which the topic was mentioned and the suggested solution (where supplied). The seven respondents were each given an opportunity to identify up to three problem topics. A total of 16 topics were identified against a potential maximum of 21 topics.

Table 7: Survey problems reported

\begin{tabular}{|l|l|l|}
\hline Problem topic & Frequency & $\begin{array}{l}\text { Suggested } \\
\text { solution }\end{array}$ \\
\hline Bandwidth & 3 & Budget \\
\hline Software acquisition & 2 & Budget \\
\hline Up to date computers & 2 & Budget \\
\hline Inter-campus connectivity & 1 & Unspecified \\
\hline IT strategy definition & 1 & Budget \\
\hline Network security & 1 & Unspecified \\
\hline Publications database & 1 & Unspecified \\
\hline Role of IT & 1 & Budget \\
\hline Storage management & 1 & Unspecified \\
\hline Student email addresses & 1 & Unspecified \\
\hline Systems integration & 1 & Budget \\
\hline Trained it staff & 1 & Skills \\
\hline Total & $\mathbf{1 6}$ & \\
\hline
\end{tabular}

The next section of this paper explores the analysis of the data findings.

\section{ANALYSIS}

This section examines the research findings in three main areas: the status of maturity ranked by Bschool respondent; the status of maturity ranked by question topic; and the most pressing ICT problems identified in the survey.

\section{Analysis by B-School Respondent}

Although only $50 \%$ of AABS-member B-schools participated in the survey, it is clear that there is a significant difference between the lowest and highest maturity scores reported. The lowest-scoring $B-$ school (B-School A) achieved a total maturity score of 46 points, which was slightly more than half of the next-lowest scoring of the respondents, and roughly one third of the score of the highest scoring B-school (135 maturity points) (see Table 4). B-school A had a SD in its score of 0.53 , the lowest overall SD of all respondents, indicating a high degree of consistency of the low level of maturity reported across all of the question areas. This confirms B-school A as being most in need of 
assistance in increasing its maturity of strategic and operational ICT. The top two B-schools based on their self-assessments distanced themselves from the other respondents, not only in terms of their scores, but also the extent to which they commented on their responses to the questions. These two B-schools combined accounted for 44 out of 45 comments made for the whole survey group, indicating a higher level of maturity in terms of their ability to pass comment on the maturity questions and their responses. The top-scoring B-school also had the second lowest SD of the survey group (0.93), indicating a relatively high degree of consistency in all of the maturity ratings assigned. The remaining four respondents had a relatively narrow spread in their average maturity scores (from 1.98 to 2.35), and had a similarly narrow range of SD for their average maturity ratings (with 0.97 to 1.15), indicating a relatively consistent spread of scores within the majority rating for each of the questions responded to by each of the B-schools.

In summary, three categories of respondent could be identified: the leaders, B-schools $G$ and $F$; the followers, B-schools E to B; the laggard, B-school A. Given the objectives of the AABS, it would be appropriate for lessons learned from the achievement of the relatively higher maturity by the leading schools to be shared with the remainder of the respondents.

\section{Analysis by Question Topic}

The second area of analysis is in terms of the maturity of rating reported for each of the question topics (see Table 5). There were three groups of maturity ratings across the 40 question topics measured. The highest-rated group (the top six questions, scoring between 3.0 and 3.3) all achieved the assessment of having a formal approach, although further progress still needs to be made. Indeed, not one of the 40 question topics achieved a score higher than 3.3, indicating that when looking at the status of the average of all the topics across all of the respondent B-schools, there are two further higher levels of maturity to be achieved. The second group of question topics was the largest (comprising 24 questions out of a total of 40, with a rating of between 2.0 and 2.9). This group of questions falls into the area where initial action has been taken, but the approach is largely informal. As can be seen from the figures in Table $6,23 \%$ of the total number of maturity ratings fell into maturity level 2. This group of topics covered a wide range of strategic and operational issues and indicates the broad scope of the need for improvement in maturity in terms of both the strategic and operational use of ICT among the respondents to this survey. The third and final group of question topics scored below 2.0 (roughly $30 \%$ of the total responses as indicated in Table 6). These ten topics, representing $25 \%$ of all the question topics contained in the survey, are those where the topic is understood by the survey respondents, but no action has yet been taken. In summary, the ranking of the question topics by maturity rating should help the response to the survey and other members of the $A A B S$ to focus on those areas where experience already exists within the AABS membership, and where the greatest opportunity for learning from prior experience, sharing of ideas and collaboration might be leveraged. The corollary to this is that the 10 lowest-ranked topics are those where the greatest level of innovation (little or no experience exists in many of the B-schools) will need to be made by the Association as a whole in terms of improving the average maturity rating.

\section{Problem Areas Identified}

The final area of this analysis focuses on the specific problems identified by the respondents (see Table 7). Twelve individual problem areas were identified, the most frequently mentioned being bandwidth. In over $30 \%$ of problems mentioned, no specific solution was identified, but in nearly $60 \%$ of cases additional funding (budget) was identified as being the possible solution. In only one case, the single instance of additional trained IT staff being required, was the issue of skills identified as a possible solution. In summary, the respondents have indicated in their assessments that their most pressing problems can be solved most often by additional funding.

\section{Analysis Summary}

It is interesting to note that a significant opportunity exists to meet the objectives of the AABS through the sharing, learning and collaborating which can arise through the understanding of the status of the strategic and operational use of ICT by those members of the Association who responded to the survey. Unsurprisingly, when applying the Pareto rule ( 80 / 20 rule), approximately $80 \%$ of all 280 responses were rated from zero to three, whilst approximately $20 \%$ of all the responses were rated 
from four to five (see Table 6). This suggests that should respondents who had a high level of maturity be willing to share their experiences, skills and knowledge with the less mature of the members of the survey respondent group, the motivation for the research to be conducted will have been justified. In addition, through further collaboration, those B-school members of AABS who wish to do so should now feel confident that they have access to a resource within the AABS network to assist them. However, this assistance is not automatic, and will be subject to negotiation through the management and members of the Association. In summary, there is much to be done to improve the overall performance of the use of ICT within the members of AABS that responded to this survey.

\section{VALUE OF THE RESEARCH}

This research project was undertaken in support of the objectives of the AABS. However, the value of the findings of the research could extend well beyond only the members of the Association that took part in the research project, or indeed all of the current members of the Association. With approximately 50 B-schools in Africa (Reed, 2006), an opportunity exists to expand the research beyond even the current membership of the AABS, as a pan-African initiative. This would then bring value in terms of an understanding of the potential for use of ICT, and the opportunity for learning from the more mature users of ICT, in the B-school community across Africa as a whole. This would bring value in terms of improving the performance not of one or more individual B-schools, but rather the whole B-school sector in Africa compared to the B-school sector in other continents around the world.

For those members of the association who did respond to the survey, and who had the opportunity to receive the feedback on the responses to the survey and the analysis of those responses, there exists a significant opportunity to share, learn, and collaborate further in terms of their use of ICT. The survey results clearly indicate that there is significant opportunity to improve the maturity of use of ICT across all the survey respondents. The value of this research, therefore, will be the extent to which the members of the Association leverage the opportunity to share their current experiences, learn from each other, and collaborate on new initiatives to improve their performance through the use of ICT.

The publication of the results of this survey through this conference paper should also have the potential benefit of encouraging more members to join the Association, as well as encouraging more active participation in future activities of the Association by its current membership.

In addition, the current and future research projects into the nature of the activities and challenges facing the members of the Association could assist in securing funding to support those activities. The Association has already received some financial support (Pfeffermann, 2005), and the availability of the findings and analysis from this research should contribute to achieving additional financial support, which has been stated as one of the objectives of the Association (AABS, 2005).

Finally, the value of the research may be in helping member institutions to formulate their own action plans for improvement, and encourage future benchmarking between members in the area of ICT strategy and operations, as well as serving as a model for other areas covered by the objectives of the Association, such as curriculum and staff development.

\section{CONCLUSION}

There is little doubt that the achievement of the objectives of many of the stakeholders on the continent of Africa will only be reached through sustainable economic growth. Such growth depends in part on the performance of individuals who have had the opportunity for self-development through B-schools based in Africa. An initiative has been taken to improve the performance of those institutions through the establishment of the Association of African Business Schools. The objectives of the AABS are clearly focused on improving standards in a number of areas, in order to raise the performance of the members of the Association, including their use of ICT.

This research project, although exploratory in nature, has already helped to identify the status of the use of ICT within a number of members of the Association. The fact that this research project took place should have already helped to confirm to the members of the Association that tangible benefits can be achieved in terms of sharing, learning and collaboration in a number of areas, in this case with 
specific reference to ICT. The real test of the value of this research will be in the actions taken in the coming months and years to build on the existing successes already achieved and to improve future performance in the way in which ICT is used to support the objectives of the individual member schools as well as of the Association as a whole.

\section{REFERENCES}

AABS (Association of African Business Schools). 2006. About us [Online] Available from: www.aabschools.com/content/Default.aspx [Accessed: 18/07/2006].

Applegate LM, McFarlan FW \& McKenney JL. 1999. Corporate information systems management: text and cases. $2^{\text {nd }}$ ed. Singapore: McGraw-Hill.

Best Practices LLC. 2003. What is benchmarking? [Online] Available from: www.best-inclass.com/site_tools/faq.htm\#best_practice [Accessed: 02/09/2003].

Better product design. Undated. Process maturity/capability maturity [Online] Available from: www.betterproductdesign.net/maturity.htm [Accessed: 20/05/2004].

Binedell N. 2006. Knowledge sharing key to Africa's growth, Business in Africa [Online] Available from: www.businessinafrica.net/features/education/176405.htm [Accessed: 18/07/2006].

CIA (Central Intelligence Agency). 2006. World Fact Book. [Online] Available from: www.cia.gov/cia/publications/factbook/index.html [Accessed: 18/07/2006].

Crosby PB. 1979. Quality is free. New York: McGraw-Hill.

Easterby-Smith M, Thorpe R \& Lowe A. 1991. Management research: an introduction. London: Sage Publications.

Elliott S \& O'Dell C. 1999. Sharing knowledge and best practices. Health Forum Journal, 42(3):3438.

Garcia S. Undated. Evolving improvement paradigms: Capability Maturity Models and ISO/IEC 15504 [Online] Available from: www.sei.cmu.edu [Accessed: 11/03/2003].

Gordon JR \& Gordon SR. 1999. Information systems: a management approach. $2^{\text {nd }}$ ed. Orlando: Dryden Press.

Hussey J \& Hussey R. 1997. Business research. Basingstoke: Palgrave.

ITWeb. 2006. IT in demand snap poll [Online] Available from: itnews@e-news.co.za [Accessed: $13 / 02 / 2006]$.

Leedy P \& Ormrod JE. 2001. Practical research: planning and design. 7th ed. New Jersey: PrenticeHall.

Miles MB \& Huberman AM. 1994. Qualitative data analysis. $2^{\text {nd }}$ ed. London: Sage.

Oz E. 2006. Management information systems. $5^{\text {th }}$ ed. Boston: Thomson Course Technology

Pfeffermann G. 2005. Give Africa's B-schools a boost, Business Week [Online] Available from: www.businessweek.com/magazine/content/05_52/b3965083.htm [Accessed: 18/07/2006].

Reed J. 2006. Africa unites to raise standards, Financial Times Deutschland [Online] Available from: www.ftd.de/karriere_management/business_english/83158.html [Accessed: 18/07/2006].

SEI (Software Engineering Institute). 2002. CMM-I frequently asked questions [Online] Available from: www.sei.cmu.edu [Accessed: 16/10/2003]. 
Welman C \& Kruger F. 1999. Research methodology for the business and administrative sciences. Cape Town: Oxford University Press. 